\title{
Phenetic relationship between Malvaceae s.s. and its related families
}

\author{
Eman M. Shamso* and Adel A. Khattab
}

Department of Botany and Microbiology, Faculty of Science, Cairo University, Giza, Egypt.

*Corresponding author:e.shamso@yahoo.com

\begin{abstract}
Systematic relationships in the Malvaceae s.s. and allied families were studied on the basis of numerical analysis. 103 macro- and micro morphological attributes including vegetative parts, pollen grains and seeds of 64 taxa belonging to 32 genera of Malvaceae s.s. and allied families (Sterculiaceae, Tiliaceae, Bombacaceae) were scored and the UPGMA clustering analysis was applied to investigate the phenetic relationships and to clarify the circumscription. Four main clusters are recognized viz. Sterculiaceae s.s. cluster, Tiliaceae- Exemplars of Strerculiaceae cluster, Malvaceae s.s. cluster and Bombacaceae s.s. - Exemplars of Sterculiaceae and Malvaceae cluster. The results delimited Sterculiaceae s.s. and Tiliaceae s.s. to containing the genera previously included in tribes Sterculieae and Tilieae respectively; also confirmed and verified the segregation of Byttnerioideae of Sterculiaceae s.l. and Grewioideae of Tiliaceae s.l. to be treated as distinct families Byttneriaceae and Spermanniaceae respectively. Our analysis recommended the treatment of subfamilies Dombeyoideae, Bombacoideae and Malvoideae of Malvaceae s.l. as distinct families: Dombeyaceae, Bombacaceae s.s. and Malvaceae s.s. and the final placement of Gossypium and Hibiscus in either Malvaceae or Bombacaceae is uncertain, as well as the circumscription of Pterospermum is obscure thus further study is necessary for these genera.
\end{abstract}

Key words: Byttneriaceae, Dombeyaceae, Phenetic relationship Spermanniaceae, Sterculiaceae s.s., Tiliaceae s.s.

\section{Introduction}

Malvales s.l. are a group of families of flowering plants estimated to contain 339 genera with 6133 known species (Christenhusz, and Byng, 2016) distributed throughout the tropical and temperate regions of both hemispheres, three families are endemics: Muntingiaceae (W Tropical America), Sphaerosepalaceae and Sarcolaenaceae (Madagascar) (Stevens 2001 onwards 2014); the largest family is Malvaceae with 244 genera including 4225 species and the smallest Muntingiaceae represented by 3 species belonging to 3 genera (Christenhusz, and Byng, 1.c.). Members of this order contain many economically important taxa as fibers (Gossypium); food and flavouring (Theobroma cacao), wood plants (Tilia); as well as medicinal and ornamental garden plants (Simpson 2010). The largest genera in terms of number of species are
Hibiscus (580, including Pavonia, etc.), Sida (200), Abutilon (100), Dombeya (225), Triumfetta (150, Grewia (290) (Stevens 1.c.).

Malvales can often be recognised by spiral, pulvinate leaves that often have palmate venation; stellate or fasciculate hairs or peltate scales, or less often with unicellular hairs, sometimes also with glands. Flowers in various types of basically cymose inflorescences, or less often solitary, mostly bisexual, usually actinomorphic, 5-merous, commonly with a double perianth, often provided with an epicalyx. Petals free or sometimes basally adnate to the filament tube, contorted, imbricate or valvate, sometimes reduced; stamens basically in two cycles, mostly five to very numerous, the filaments usually connate into a tube. Fruits usually dry, dehiscent or indehiscent, less often fleshy, rarely winged, the capsule sometimes muricate or spiny, and the seeds 


\section{Eman M. Shamso and Adel A. Khattab}

or inside of the carpel walls are sometimes conspicuously hairy. The bark is often very fibrous and tough because of the stratified phloem. (Stevens 2001 onwards 2014; Takhtajan 2009).

Malvales were traditionally circumscribed as four main families referred by many authors as"Core Malvales" viz.: Bombacaceae, Sterculiaceae, Tiliaceae and Malvaceae (Cronquist 1988; Takhtajan 1997). Major disagreements existed between different taxonomic treatments and the circumscriptions of these families and their systematic position have long been problematic. A close relationship among these families, however, has generally been recognized since the time of Linnaeus (1753) and was recently confirmed by morphological, anatomical, chemical and molecular data (Chase et al. 1993, Soltis et al. 1997, Judd \& Manchester 1997, Alverson et al. 1998, Fay et al. 1998 and Bayer et al. 1999).

Bentham \& Hooker (1862) included Malvaceae, Sterculiaceae and Tiliaceae in the "cohort Malvales", and divided the order into three families: Malvaceae (incl. Bombacaceae), Tliliaceae (incl. Elaeocarpaceae) and Sterculiaceae with several tribes.

Schumann (1890-1897) separated tribe Elaeocarpeae of Tiliaceae with some genera and raised a separate family Elaeocarpaceae, accordingly, the order Malvales consists of Tiliaceae, Sterculiaceae, Malvaceae, Bombacaceae and Elaeocarpaceae. The Elaeocarpaceae was included in Tiliaceae by most authors although it differ from the Tiliaceae and related families in the absence of stellate and peltate trichomes, the absence of mucilage cavities or canals (Takhtajan 2009). Edlin (1935 b) re-arranged the genera of Malvales among families and recognized six families viz.: $\quad$ Scytopetalaceae, Tiliaceae, Sterculiaceae, Buettneriaceae, Bombacaceae and Malvaceae. The main chief of his system was the re-arrangement of the family Sterculiaceae, so that it comprises only the tribe Sterculieae while the tribe Hibisceae has been transferred from the Malvaceae to the Bombacaceae; three other genera of the Malvaceae have been removed to the
Bombacaceae. Hutchinson (1967) restricted Malvales to include Malvaceae and developed a new order Tiliales to include Tiliaceae, Bombacaceae and Sterculiaceae.

Within the re-circumscribed monophyletic order Malvales, Judd \& Manchster (1997), Bayer et al. (1999) and APG II (2003) merged Tiliaceae, Bombacaceae, Sterculiaceae with Malvaceae and subdivided the enlarged family Malvaceae into nine subfamilies based on molecular, morphological and biogeographical data: Byttneroideae (including tribes Byttnerieae, Lasiopetaleae, Theobromeae and Hermannieae); Grewioideae (including most genera of former Tiliaceae); Tilioideae ( including both Tilia and Craigia); Helicteroideae (comprising most of the taxa previously included in Helictereae and Durioneae); Sterculioideae (including tribe Sterculieae); Brownlowioideae; Dombeyoideae; Bombacoideae (corresponding to former Bombacaceae without Durioneae) and Malvoideae (monophyletic but difficult to delimit from Bombacoideae).

The ndhF cladogram of Alverson et al. (1999) supported the monophyly of traditional Malvaceae but the other three traditional families are non-monophyletic; and showed nine major lineages within three well-suported clades, labelled as subfamilies: Malvoideae and Bomacoideae grouped in Malvatheca clade; Byttneroideae and Grewioideae grouped in Byttneriina clade; Sterculioideae, Tilioideae, Helicteroideae, Brownlowioideae and Dombeyoideae grouped in Malvadendrina clade. (Kubitzki and Bayer 2003, Stevens 2001 onward, 2014).

Phylogenetic studies have shown the core malvales constitute one of four major clades within an expanded Malvales clade which also includes ten families: Neuradaceae, Thymelaeaceae, Sphaerosepalaceae, Bixaceae, Cistaceae, Sarcolaenaceae, Dipterocarpaceae, Cytinaceae, Muntingiaceae, Malvaceae s.l. (incl. Bombacaceae, Tiliaceae, Sterculiaceae, Dombeyaceae and Byttneriaceae) distributed among seven monophyletic lineages (Alverson et al. 1998 \& 1999, Fay et al. 1998, Bayer et al. 1999 and Kubitzki \& 


\section{Phenetic relationship between Malvaceae s.s.}

Bayer 2003). All these families were previously considered to have malvalean affinities in some traditional treatments (APG III, 2009 \& APG IV, 2016; Le Péchon \& Gigord 2014, Stevens 2001 onwards 2014, Shipunov 2016). The same concept was adopted by Reveal (2012) with slight modification in which the order was expanded to include more than ten families. In Reveal's system the Sterculiaceae, Tiliaceae, Bombaceaceae, Dombeyaceae and Byttneriaceae were treated as separate families.

The present study aims at applying numerical method for examining morphological variation, inferring phenetic relationships among the examined taxa, discussing the results obtained with recent classifications and confirming the position of the family Malvaceae s.s. and the allied families

\section{Material and Methods Plant materials:}

In the present study, sixty-four cultivated and indigenous taxa belonging to thirty-two genera of four families viz. Malvaceae, Sterculiaceae, Tiliaceae and Bombacaceae (Malvaceae s.l. sensu Bayer et al.) were selected for examination constituting the operational taxonomic units (OTUs), Appendix (1).

The investigation is based on herbarium materials from Egypt, Arabia, Jordan, Libya, Sudan and Europe kept in Cairo University Herbarium (CAI) and the Agricultural Research Centre, Flora \& Phytotaxonomy Herbarium (CAIM), as well as fresh materials grown in various habitats in addition to botanical and public gardens in Egypt.

Identification was confirmed by consulting literatures e.g. Bircher 1960; Bircher \& Bircher 2000; Täckholm 1974; El Hadidi \& Boulos 1988; Huxley et al. 1992; Boulos 2000, 2009; Shamso \& Hamdy 2010. Nomenclature of all taxa has been updated according to several websites (www.Tropicos.org; www.theplantlist.org; www.ipni.org).

\section{Morphological observations:}

characters

Appendix (2) shows the characters and character states scored for plant, pollen and seed morphology averaged for each OTU. In total 103 characters were taken into consideration, comprising eighteen quantitative and eighty-five qualitative characters. Forty-five of the qualitative characters were scored as binary and the remaining were scored as multi-state characters.

The recorded measurements of the whole plant and leaves were based on mature plant, all flower descriptions were taken at anthesis (if available) with the dimensions of sepals and petals given in term of length (from base to apex) $\mathrm{x}$ width (at the broader point), fruit and seed diameter included spines or wings ( if present). The data of pollen morphology were mainly obtained from Erdtman 1952, Hosni \& Araffa 1991, El Naggar 2004, Lakshmi 2003, El Husseini 2006, Perven et al. 2004, Perveen \& Qaiser 2007, and Hamdy \& Shamso 2010.

\section{Data analyses:}

The package of classificatory programs used in the numerical analysis of the data matrix is PC-ord version 5 for windows (McCune 1997). Each of the resulting dendrograms has a certain \% of chaining which is an expression of its clustering intensity. Low values of \% chaining indicate a high clustering intensity of the dendrogram, and vice versa. The higher the clustering intensity, the more discrete (and taxonomically reliable) the groups in the dendrogram are. Comparison between the resulting dendrograms was carried out manually to select those which were closest to each other and to traditional systems of classification. The $\%$ chaining of the resulting dendrograms facilitated the task of comparison between them manually and selecting the most 'appropriate' dendrogram for further discussion.

\section{Results}

Figure (1) shows the UPGMA phenogram comprising all OTUs in the present work and produced by the statistical 


\section{Eman M. Shamso and Adel A. Khattab}

analysis based on 103 macro- and micromorphological characters, Appendix (2). The dendrogram separated the 64 studied malvalean taxa into two series included four main clusters at the 4.4 level of average taxonomic distance. The first series comprises two main clusters (Ia \& Ib) at a taxonomic distance level 3.55 and The second series comprises two main clusters (II a \& II b) at a taxonomic distance level 3.975

The first main cluster (Ia) consists of nine species belonging to four genera viz. Brachychiton, Pterygota, Firmiana and Sterculia. The second main cluster (Ib) is heterogeneous, comprises 19 species belonging to nine genera viz. Hermannia,
Waltheria, Glossostemon, Guazuma, Abroma, Corchorus, Grewia, Triumfetta and Tilia. At 3.328 distance level, this cluster is subdivided into two distinct groups; the first one represented the studied taxa of Tilia, Triumfetta, Glossostemon, Guazuma and Abroma. While, the second group comprises the studied taxa of Corchorus, Grewia, Hermannia and Waltheria.

The third main cluster (IIa) comprises all of the studied genera of Malvaceae s.s. except Hibiscus and Gossypium which are nested in the fourth main cluster (IIb). At 2.55 distance level, two groups are recognized; the first group is spilitting off into two subgroups at 2.2 distance level.

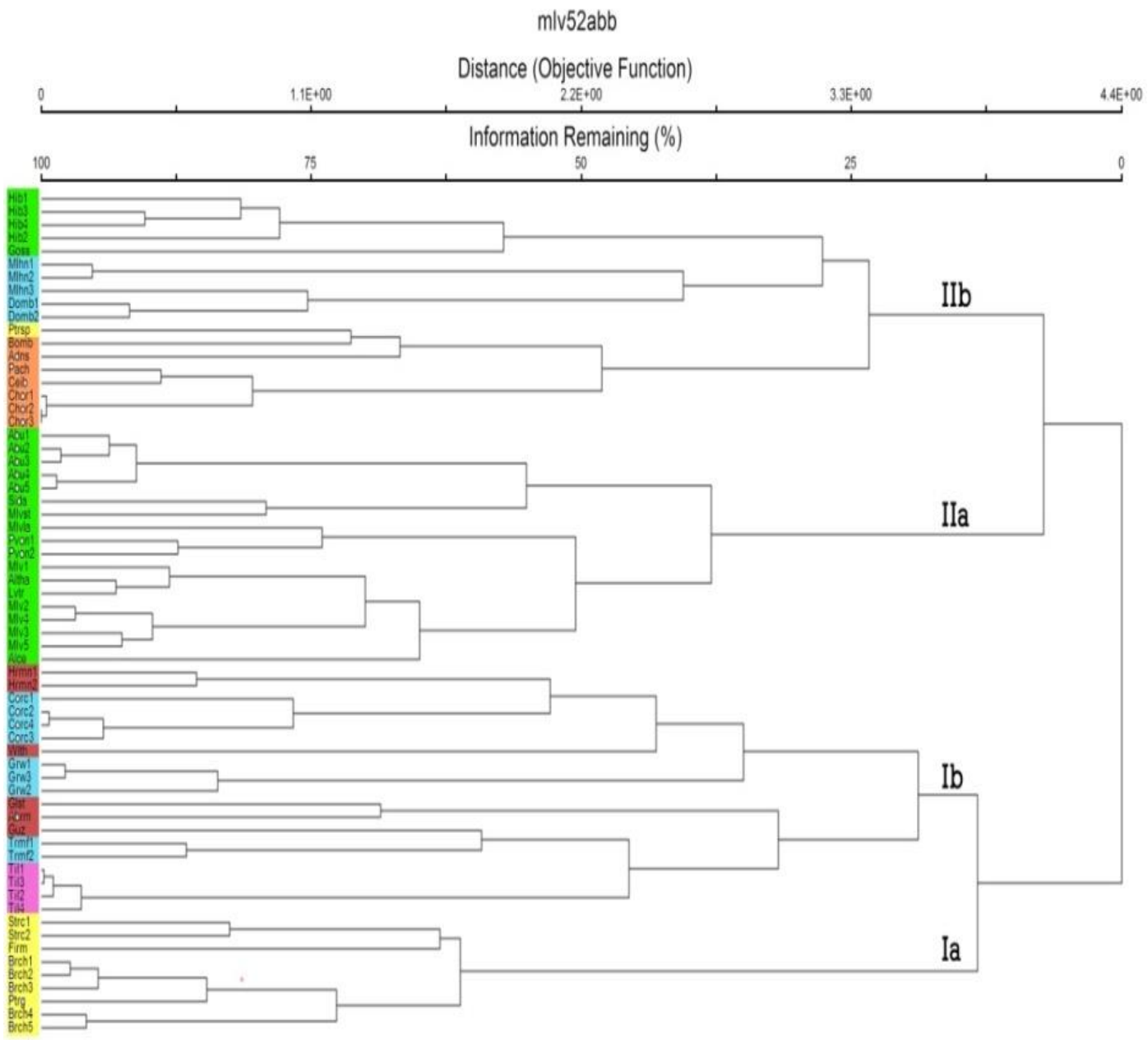

Fig. (1): The UPGMA phenogram illustrating the relationships of the species studied of Malvaceae and its allied families, based on the variation in the macro- and micromorphological characters. (For full name of taxa see appendix 3) 


\section{Phenetic relationship between Malvaceae s.s.}

The first one included the studied taxa of Malva, Alcea, Althea and Lavatera and the second subgroup included Pavonia and Malvella. While the second group composed of studied taxa of Abutilon, Sida and Malvastrum.

At 3.308 distance level, two distinct groups are found in the fourth main cluster (IIb). The first one represented studied taxa of Adansonia, Bombax, Pachira, Ceiba, Chorisia and Pterospermum. The second group splitted off at 2.99 distance level into two subgroups, the first subgroup included all studied taxa of Dombya and Melhania and the second subgroup included the studied taxa of Hibiscus and Gossypium.

\section{Discussion}

The results of the present study clearly demonstrated that the circumscription of some taxa is in accordance with previously proposed classifications, whereas other may be rejected or redefined. In traditional taxonomy, the core Malvales contains taxa divided among four families viz. Bombacaceae, Malvaceae, Sterculiaceae and Tiliaceae (Bentham \& Hooker 1862, Cronquist 1981, 1988, Thorne 1992, Cheek 2007, Takhtajan 2009). However, phylogenetic studies based on morphological and molecular data did not support the monophyly of these traditional families, and merging them into an expanded family Malvaceae s.l. to include nine subfamilies : Byttnerioideae, Grewioideae, Sterculioideae, Tilioideae, Dombeyoideae, Brownlowioideae, Helicter-oideae, and Bombacoideae (Judd \& Manchester 1997, Bayer et al. 1999, Alverson et al. 1998 \&1999, Stevens 2001 onward 2014, Kubitizki \& Bayer 2003, Baum et al. 2004, APG III 2009, APG VI, 2016, Shipunov 2016). On the other hand, Reveal (2012) treated these subfamilies as distinct families: Byttneriaceae, Sparmanniaceae (Grewioideae sensu Bayer et al. 1999), Tiliaceae, Sterculiaceae, Dombeyaceae, Berryaceae (=Brownlowioideae sensu Bayer et al. 1999), Helicteraceae, Malvaceae and Bombacaceae respectively.

The analysis of the resulted dendrogram revealed that the taxa under investigation were splitting into four main clusters within two series based on the presence or absence of epicalyx, number of anther's cells, and characters of pollen grains, these clusters were corresponding to the following families: Sterculiaceae s.s. cluster, Tiliaceaeexemplars of Sterculiaceae cluster, Malvaceae s.s. cluster and Bombacaeaeexemplars of Sterculiaceae \& Malvaceae cluster.

Sterculiaceae s.s. cluster:

Sterculiaceae is very diverse family and is characterized by a great diversity of morphological, anatomical, and palynological features. The taxa formerly classified in Sterculiaceae are distributed within the subfamilies Byttnerioideae, Dombeyoideae and Sterculoideae (Takhtajan 2009). The resulted phenogram grouped Sterculia, Brachychiton, Firmiana and Pterogota in one cluster (Sterculiaceae cluster) which characterized by unique taxonomic traits viz. unisexual or polygamous flower, colored calyx, absence of corolla, presence of androgynophore and woody follicle fruits. This result is in accordance with Wilkie et al. (2006), who concluded that the molecular analysis supports monophyly of Sterculioideae group. These taxa were delimited in tribe Sterculieae (Edlin 1935a, Schulze-Motel 1964, Hutchinson 1967), or Sterculioideae as proposed by (Bayer et al. 1999, Stevens 2001 onward, 2014). Our results support the modern concept of delimiting Sterculiaceae (Sterculioideae) to contain only genera previously included in tribe Sterculieae.

Tiliaceae-exemplars of Sterculiaceae cluster: is the largest and heterogeneous cluster, consists of exemplars of Sterculiaceae and Tiliaceae and characterized by simple dentate leaves, bisexual flowers, connate style and various types of fruits. This cluster is interesting because there have been differences of opinions over their separation into infrafamilies or as distinct families. According to Dehay (1941), Sterculiaceae are very near to the Tiliaceae, which is confirmed by the anatomy of vascular system of the petiole. Cladisticaly, the traditional Sterculiaceae and Tiliaceae are polyphyletic families and recently, most of their genera were distributed among different subfamilies: Tilioideae, Grewioideae, Sterculioideae, 


\section{Eman M. Shamso and Adel A. Khattab}

Byttneroideae, Dombeyoideae, Brownloideae and Helictrioideae within the expended Malvaceae s.l. (APG II \&III 2003, 2009; Alverson et al. 1998; Bayer et al. 1999; Kutbitzki \& Bayer 2003). Whereas, others treated them as distinct families (Cheek 2007; Takhtajan 2009 and Reveal 2012).

In his circumscription of Tiliaceae, Takhtajan (2009), included several families accepted by Doweld (2001) and by Cheek (2007), all at the rank of tribes in two subfamilies: Tilioideae and Brownlowideae. Thorne \& Reveal (2007) shifted Tilioideae s.s. to Malvaceae s.l. and developed a new family Grewiaceae for other genera. Cheek (2007) and Reveal (2012) assigned only tribes Tilieae and Craigieae to Tiliaceae s.s. and the rest are placed in Sparmanniaceae (subfamily Grewioideae sensu Bayer et al. 1999). The examined Tilia species distinct from the other taxa by deciduous leaves, bracts differed from the foliage leaves and adnate to the peduncle, fruit nutlet with one ovoid seeded, pollen tricolporate with reticulate sculpture, thus the delimitation of the Tilia spp. in the present work is in agreement with Cheek and Reveal's concept.

The grouping of the remaining genera previously assigned in family Tiliaceae: Grewia, Triumfetta, Corchorus, and some genera of Sterculiaceae: Abroma, Guazuma, Glossostemon, Hermannia and Waltheria in one cluster is interesting because there have been differences of opinion over their separation into sub-families (Takhtajan 2009) or as distinct families (Cheek 2007 \& Reveal 2012).

Takhtajan (2009) placed the studied species of Grewia, Triumfetta, Corchorus in tribes Grewieae, Triumfetteae and Corchoreae respectively of subfamily Tilioideae, family Tiliaceae; while Cheek (2007) and Reveal (2012) placed the genera in separate family Sparmanniaceae (subfamily Grewioideae sensu Bayer et al. 1999). In Takhtajan's treatment, three subfamilies were recognized within Sterculiaceae: Byttenerioideae, Dombeyoideae and Sterculioideae. The Byttenerioideae comprises genera traditionally assigned to tribes Hermannieae, Theobromeae, Byttnerieae and Lasiopetaleae of Sterculiaceae (Bayer et al. 1999 and
Whitlock et al. 2001). In particular, there are so many differences between the Byttnerioideae and Sterculioideae that Edlin (1935b) proposed to accept them as two separate families Byttneriaceae and Sterculiaceae respectively.

Our results showed that there are close relationship between the studied genera which belonging to both subfamilies Byttnerioideae and Grewioideae. Where Guazuma, Glossostemon and Abroma (Byttnerioideae, tribes Theobromeae \& Byttnerieae) are clustered with Trimufetta (Grewioideae) in having perennial shrubs, leaf-lamina wide ( $>4 \mathrm{~cm}$ width) with linearlanceolate stipules. Fruit-capsule terete or angled in outline, with echinate or tuberculate surface; while the remaining studied taxa of Bytteneroideae viz. Waltheria, and Hermannia (tribe Hermannieae) are nested with Corchorus and Grewia (Grewioideae) in having annual or perennial herbs sometimes low shrubs, leaflamina narrow (up to $4 \mathrm{~cm}$ width) with subulate stipules. Fruit glabrous and angled or lobed in ouline. However, the molecular evidence supported by morphology has shown that Sparmanniaceae are closely related to Bytteneriaceae (Grewioideae and Bytterinoideae sensu Bayer et al. 1999). Excluding the Tilia group, the analysis of this cluster certained this close relationship and interspersed among the studied genera of Sparmanniaceae and Bytteneriaceae (Byttnerioideae and Grewioideae sensu Bayer et al.1999), and its accentuating the need for further investigation of the possibility of tracing the phylogenetic relationship between both families Sterculiaceae s.l. and Tiliacea s.l.

Malvaceae s.s. cluster:

Malvaceae s.s. is a large family, traditionally divided into 5 tribes viz. Malopeae, Hibisceae, Malveae, Abutileae and Ureneae based on the characters of fruits (Hutchinson 1967), while Schultze-Motel (1964) recognized three tribes. Recently, Takhtajan (2009) recognized four tribes in Malvaceae viz.: Kydieae, Hibisceae, Gossypieae and Malveae. In the present work, the studied taxa of Malvaceae s.s. were grouped in one cluster except Hibiscus and Gossypium which were separated earlier 


\section{Phenetic relationship between Malvaceae s.s.}

on the basis of the character of flowers and the capsular fruits (will be discussed latter) in contrary to other genera of Malvaceae which having herbaceous plants rarely shrubs, flowers mostly small (up to $10 \mathrm{~mm}$ in diam.), with emarginated petals, staminal tubes relatively short (up to $10 \mathrm{~mm}$ long), fruit schizocarp with depressed apex and pollen always spinose with pantoporate apertures. This cluster is splitting off into two groups owing to the presence or absence of epicalyx, dehiscence of fruit and number of seeds. The first group splits off into two subgroups and characterized by the presence of epicalyx, mericarp indehiscent and one seeded. The first subgroup includes the studied taxa of genera: Malva, Alcea, Althaea and Lavatera which are included in tribe Malveae by most authors (Schultze - Motel 1964, Hutchinson 1967 \& Takhtajan 2009) and the second subgroup includes Pavonia and Malvella. Pavonia is usually placed in a separate tribe Ureneae by most authors (Schultze-Motel 1964, Hutchinson 1967 \& Cheek 2007). While, Takhtajan (2009) placed the genus with Hibiscus in tribe Hibisceae. The separation of studied taxa of Pavonia from Hibiscus doesn't support the concept of Takhtajan (o.p.). The genus Malvella (tribe Malveae) was nested with Pavonia (tribe Ureneae) due to short petiole (up to $50 \mathrm{~mm}$ long), petals acute to rounded apex, glabrous staminal tubes, and schizocarpic fruit with 5-7 mericarps, each with ellipsoid to pyriform one- seeded. This result didn't agree with the placement of Malvella within tribe Malveae by most authors. The circumscription of this genus needs further study.

In the second group, Sida, and Malvastrum clustered with Abutilon which are included in tribe Abutilieae by most authors due to the absence of epicalyx, free styles and schizocarpic fruit with dehiscent mericarp and 2-3 seeded. According to Hutchinson (1967), tribe Abutileae comprises two subtribes: Abutilinae (include Abutilon) and Sidinae (include Sida and Malvastrum). The tribe Abutileae however, was included within Malveae in the system of Takhtajan (2009). Based on molecular data Reveal (2012) separated both subtribes Sidinae and Abutilinae from Malveae under tribe Sidieae.
Our data support the previous work of treating tribe Abutileae (Sidieae sensu Reveal 2012) with its two subtribes as distinct from Malveae.

Bombacaceae-exemplars of Sterculiaceae \& Malvaceae cluster: is heterogeneous cluster, consists of studied genera of Bombacoideae, Dombeyoideae and exemplars of Molvoideae (sensu Bayer et al. 1999). Two groups are recognized; the first group included Pterospermum and the studied taxa of Bombacoideae. Pterospermum is traditionally placed in Sterculiaceae s.l. in tribe Dombeyeae with Dombeya and Melhania (Schultze-Motel 1964,), and in Helictereae, (Hutchinson 1967 \& Takhtajan 2009). According to Cheek (2007) the genera traditionally included in the former tribe Helictereae have on molecular ground been placed elsewhere. Accordingly, Pterospermum were moved with Dombeya to be placed in a separate family Pentapetaceae which characterized by uniseriate androecium, 3-bracteate epicalyx and spiny pollen grains. However, Bayer et al. (1999) transferred the genus to expanded Dombeyoideae based on molecular data. In the present work, Pterospermum nested with Bombax in Bombacoideae group in contrast to previous classification, having simple to lobed leaves, presence of carpophores, capsule woody and angled in outline, with winged seeds and pollen with echinategranulate sculpture. However, the delimitation of Pterosrmum is obscure and needs more studies.

Bombacoideae is a lineage of Malvaoideae (Alverson et al. 1999, Bayer et al. 1999, Nyffler et al. 2005 \& CarvalhoSobrinho 2016), it has been treated as a separate family by many taxonomists (Hutchinson 1967, Takhtajan 1997 \& 2009, Cheek 2007 \& Reveal 2012). While, Bentham \& Hooker (1862) have given it only a tribal status under their Malvaceae (Bombaceae). Morphologically, Bombacaceae is recognized by deciduous trees, palmately compound leaves, stipules deciduous, flowers showy and mostly solitary with long petals ( $>50 \mathrm{~mm}$ long), fruit capsule, woody and long (>10 cm long), hairy inside and pollen tricolporate with reticulate sculpture rarely spinose. The 


\section{Eman M. Shamso and Adel A. Khattab}

present work supports the treatment of Bombacoideae as a distinct family Bombacaceae as proposed by Cheek (2007) \& Reveal (2012).

The second group splitting off into two subgroups ; the first subgroup comprises the studied taxa of two genera viz. Dombeya and Melhania belonging to subfamily Dombeyoideae (Dombeyaceae sensu Reveal 2012), owing to evergreen, ascending to procumbent shrubs, leaves simple, with persistent stipules, epicalyx 3 units, flowers in axillary cymes, with free lanceolate sepals, corolla up to $15 \mathrm{~mm}$ long, stamens bicelled with spathulate staminodial appendages altenate with stamens, fruit non woody, globose capsule $(<2 \mathrm{~cm}$ long), glabrous inside and pollen triporate with echinatefoveolate sculpture.

Dombeyoideae was formerly included in tribe Dombeyeae (Bentham \& Hooker 1824, Hutchinson 1967) and was treated as subfamily Dombeyoideae (Takhtajan 2009) of family Sterculiaceae. Molecular studies (Bayer et al. 1999, Alverson et al. 1999 \& APG II, III 2003, 2009, Stevens 2001 onward 2014) recognized Dombeyoideae as a subfamily of Malvaceae s.l., while Cheek (2007) and Reveal (2012), treated it as a separate family: Pentapetaceae or Dombeyaceae respectively. The present work is agreement with Reveal in treatment Dombeyoideae as a separate family Dombeyaceae

The second subgroup comprises two genera viz. Gossypium and Hibiscus (Malvaceae s.s.), which are characterized by solitary flowers, epicalyx 6-12 units, connate calyx, corolla $15-50 \mathrm{~mm}$ long, stamens numerous, unicelled, stigma capitate to clavate, fruit depressed capsule with many seeded, seeds reniform rarely ovoid, hairy sometimes glabrous, pollen pantoporate with echinate - foveolate sculpture. Both genera were placed in tribe Hibisceae by SchultzeMotel (1964), Hutchinson (1967), Kubitzki
\& Bayer (2003), Takhtajan (2009) while Reveal (2012) placed them in two separate tribes Hibisceae and Gossypieae respectively. However, Edlin (1935b) transferred Hibisceae to Bombacaceae based on its woody or shrubby characters. According to Bayer et al. (1999), the molecular data provide weak support for the monophyly of Malvoideae (Malvaceae s.s.), thus including Hibisceae and Gossypieae within Malvoideae. Although, Takhtajan (2009) and Reveal (2012) have included Hibisceae and Gossypieae in Malvaceae, in this work the separation of Hibiscus and Gossypium from the rest of Malvaceae s.s. may support the concept of Edlin (1935b).

\section{Conclusion}

Our data strongly support the monophyly of Malvaceae s.s. and Bombacaceae s.s., whereas both Sterculiaceae and Tiliaceae are highly polyphyletic. Sterculiaceae s.s. and Tiliaceae s.s. are delimited to containing the genera previously included in tribes Sterculieae and Tilieae respectively. The close relationship and interspersed among the studied genera of Grewioideae and Byttnerioideae are confirmed and verified the segregation of Byttnerioideae of Sterculiaceae s.l. and Grewioideae of Tiliaceae $s . l$. to be treated as distinct families Byttneriaceae and spermanniaceae respectively, as proposed earlier by Reveal (2012). Our analysis also recommended that subfamilies Dombeyoideae, Bombacoideae and Malvoideae of Malvaceae s.l. treated as distinct families: Dombeyaceae, Bombacaceae s.s. and Malvaceae s.s. as Cheek (2007) and Reveal (2012). The final placement of Gossypium and Hibiscus in either Malvaceae or Bombacaceae is uncertain, as well as the circumscription of Pterospermum is obscure thus further study is necessary. 


\section{Phenetic relationship between Malvaceae s.s.}

\section{Identification Key of the studied genera based on the macro and micro- morphological characters:}

1- $\quad$ Epicalyx present

- Epicalyx absent

2- $\quad$ Tree plants

- Herbs or shrubs plants

3- Flowers unisexual or polygamous, petals absent, fruit of 1-5 follicles.

- Flowers bisexual, petals present, fruit capsule or nutlets.

4- $\quad$ Follicle membranous, leaf-like, with reticulate veined, apex notched. Seeds 4 .......Firmiana

- Follicle woody, without veins, apex beaked. Seeds more than 4

5- $\quad$ Perianth partite, 5-6 parts, linear-oblong, seeds winged Petrygota Perianth connate, campanulate to tubular, with 5 lobes, seeds unwinged

6- $\quad$ Follicles densely stellate hairy inside, seeds within the follicle enclosed by honey comb-like exotestas Brachychiton Follicles glabrous inside or slightly hairy along margins, seeds born along the margins of the suture without exotestas Sterculia

7- $\quad$ Fruit nutlets, bracts adnate and differentiated from the foliage leaves ......................Tilia

- Fruit capsule, bract not adnate and similar to the foliage leaves

8- $\quad$ Flowers arranged in axillary cymes, petals differentiated into claw and limb.

9- $\quad$ Flowers solitary, petals undifferentiated into claw and limb

10- Sepals 3, petal-limb divided into 2- lobes, capsule indehiscent with tuberculate surface. Pollen- aperture tricolporate and exine reticulate

Guazuma

- Sepals 5, petal limb undivided, capsule dehiscent, turbinate with 5 wings. Pollen -aperture tribrevicolpate and exine echinate-granulate.

Abroma

11- Evergreen trees, leaves simple to lobed, with dentate margin, with staminodial appendages and androgynophore; seeds winged. Pollen-aperture triporate and exine echinategranulate.

Pterospermum

- Deciduous trees, leaves palmately compound, with entire margin, neither staminodial appendages nor androgynophore; seeds unwinged. Pollen-aperture tricolporate and exine reticulate.

Bombax

12- Anther unicelled.

Anther bicelled

13- Plant 50-100 cm tall, flowers solitary, styles free, schizocarpic fruit more than 10 mericarps, mericarp hairy, dehiscent, with 2-3 seeded.

Abutilon

- Plant up to $50 \mathrm{~cm}$ tall, flowers arranged in fascicles, styles connate, schizocarpic fruit 5mericarps, mericarp glabrous, mostly indehiscent, with one seeded..........................Sida

14- Herbs, fruit dehiscent.

Shrublets, fruit indehiscent.

15- Leaves pinnately nerved, androecium 5 - stamens.

Leaves palmately nerved, androecium more than 10- stamens

Corchorus

16- Leaf margin entire, flowers solitary, stamens with free dilated filaments; capsule angled, with many seeded, seeds reniform with wrinkled testa. Pollen tri- to tetra-colporate ...Hermannia Leaf margin dentate, flowers in fascicles, stamens with united filaments; capsule teret, with one seeded. seeds obovoid with striate testa. Pollen tetra- to penta- colporate

Waltheria

17- Stipules deciduous, fruit drupe, orange to red, glabrous to hairy. Seeds with membranous margin

Grewia

Stipules persistent, fruit capsule, pale to dark brown, with strongly echinate process. Seeds with 3-4 angles

18- Petals with bearded base, capsule non woody, angled, with 2-4 seeded, seeds brown, testa alveolate to reticulate. Pollen with reticulate-perforate exine

Trimufetta 


\section{Eman M. Shamso and Adel A. Khattab}

- Petals without bearded base, capsule woody, teret, more than 4- seeded, seeds grayish mottled with brown, testa smooth. Pollen with reticulate exine Glossostemon

19- Deciduous trees, leaves palmately compound, stipules deciduous, corolla more than 50mm long. Fruit capsule, woody, cylindrical to elliptic, more than $10 \mathrm{~cm}$ long, inner surface hairy

Evergreen shrubs or herbs, leaves simple to lobed, stipules persistent, corolla less than $50 \mathrm{~mm}$ long. Fruit capsule or schizocarp, non woody, globoid or discoid, up to $4 \mathrm{~cm}$ long, inner surface glabrous

20- Stem subglabrous to hairy, androecium more than 10 stamens, anthers unicelled

Stem prickly, androecium 5- stamens, anthers bicelled

21- Flowers solitary, petals free; capsule indehiscent, seeds reniform, glabrous. Pollen tri-porate and echinate-foveolate exine.

Adansonia

Flowers in axillary cymes, petal connate at base, capsule dehiscent, seeds ovoid, densely hairy. Pollen tri-colporate and reticulate exine

Pachira

22- Leaf margin dentate, flowers solitary, petals free, staminodial appendages present as coronalike and whorled at the lower part of stamina tube

Chorisa

- Leaf margin entire, flowers in fascicles, petals connate at base, no staminodial appendages

23- Shrublets to shrubs, carpels 3-5, fruit a loculicidal capsule with 2- many seeds

Ceiba

Herbs ,carpels more than 5, fruit schizocarp, mericarp one seeded

24

Stamens numerous with unicelled anthers, no staminodial appendages, capsule with many

seeds

- Stamens 5-10 with bicelled anthers, with spathulate staminodial appendages alternate with stamens, capsule with 2-3 seeds.

25- Leaf margin entire, epicalyx-units 3, broadly ovate-cordate, apically toothed, style connate. Fruit apex beaked, seeds ovoid ............................................... Gossypium Leaf margin dentate, epicalyx-units 6-12, filiform-linear, entire, style free. Fruit apex depressed, seeds reniform .

Hibiscus

26- Stamens 5, flowers enclosed by 3- broadly cordate to ovate bracteoles, seeds

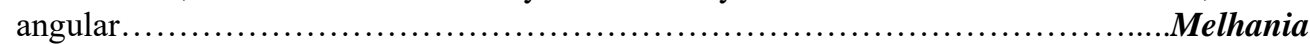

Stamens 10, flowers subtended by 3 - linear-lanceolate, seeds teret ................Dombeya

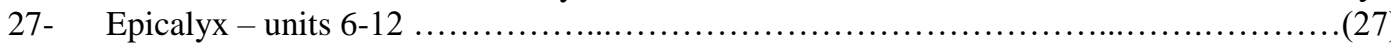

Epicalyx - units 2-3

28- Epicalyx - units free, petal- apex acute to rounded, styles twice as many as carpels, with capitates stigma, carpels 5, fruit globose with 5 trigonous mericarp ...................Pavonia

- Epicalyx - units connate at base, petals - apex emarginated, styles as many as carpels, with filiform-decurrent stigma, carpels more than 5, fruit discoid with more than 5 reniform mericaps.

29- Plant $50-100 \mathrm{~cm}$ tall, flowers solitary, petals yellow to orange with bearded base; staminal tube 5-angled. Mericarps more than 10 .

Alcea

- Plant more than $50 \mathrm{~cm}$ tall, flowers in fascicles, petals pink to mauve, without bearded base; stamina tube teret. Mericarps 7-10

Althaea

30- Stipules deciduous, epicalyx - units connate at base .............................

Stipules persistent, epicalyx - units free

31- Pedicel up to $10 \mathrm{~mm}$ long, petals connate from base, with bearded base. Mericarp with awned apex Malvastrum

Pedicel more than $10 \mathrm{~mm}$ long, petals free, without bearded base. Mericarp with rounded apex

32- Leaves simple, flowers solitary, epicalyx-units deciduous, petals apex acute, styles free, with clavate stigma, mericarp inflated.

Malvella

Leaves simple and lobed, flowers in fascicles, epicalyx-units persistent, petals apex emerginate, style connate, with filiform-decurrent stigma, mericarp reniform.

Malva 


\section{Phenetic relationship between Malvaceae s.s.}

\section{Acknowledgments}

The authors thank Dr. Hasnaa A.Hosni, Cairo University for her valuable comments, Dr. Amal I. Hosny Cairo University, for the critical revision of the manuscript.

\section{References}

APG II (Angiosperm Phylogeny Group) (2003). An update of the Angiosperm group classification for the orders and families of flowering plants APG II. Bot. J. Linn. Soc., 141(4):399-436.

APG III (Angiosperm Phylogeny Group) (2009), "An update of the Angiosperm Phylogeny Group classification for the orders and families of flowering plants: APG III". Bot. J. Linn. Soc., 161 (2): 105-121,

APG IV (Angiosperm Phylogeny Group) (2016). An update of the Angiosperm Phylogeny Group classification for the orders and families of flowering plants: APG IV. Bot. J. Linn. Soc., 181 (1): 1-20.

Alverson WS, Karol KG, Baum DA, Chase MW, Swensen SM, McCourt R, Sytsma KJ (1998). Circumscription of the Malvales and repationships to other Rosidae: evidence from rbcL sequence data. Am. J. Bot. 85:876887.

Alverson W S, Whitlock BA, Nyffeler R, Bayer C, Baum DA (1999). Phylogenetic analysis of the core Malvales based on sequences of ndhF. Am. J. Bot. 86: 14741486.

Baum DA, DeWitt Simth S, Yen A, Alverson WS, Nyffeler R, Whitlock BA, Oldham RL (2004). Phylogenetic relationships of Malvatheca (Bombacoideae and Malvoideae; Malvaceae s.l.) as inferred from plastid DNA sequences. Am. J. Bot. 91: 1863:1871.

Bayer C, Fay MF, De Bruijn AY, Savolainen V, Morton CM, Kubitzki K, Alverson WS and Chase MW (1999) Support for an expanded family concept of Malvaceae: A combined analysis of plastid atpB and rbcL DNA sequences. Bot. J. Linn. Soc., 129(4): 267-303.

Bentham G \& Hooker JD (1862). Genera plantarum, vol. 1. L. Reeve and Co., London. Bircher WH (1960). Gardens of the Hesperides. The Anglo-Egyptian Bookshop.

Bircher AG \& Bircher WH (2000). Encyclopedia of Fruit Trees and Edible plants in Egypt and Subtropics. The American University in Cairo Press. CairoNew York.

Boulos L (2000). Flora of Egypt, vol.2 (Geraniaceae-Boraginaceae). Al Hadara Publishing, Cairo.

Boulos L (2009). Flora of Egypt checklist. Revised Annotated Edition. Al Hadara Publishing, Cairo.

Carvalho-Sobrinho JG, Alverson WS, Alcantara S, Queiroz Lp, Mota AC, \& Baum DA, (2016). Revisiting the phylogeny of Bombacoideae (Malvaceae): Novel relationships, morphologically cohesive clades, and a new tribal classification based on multilocus phylogenetic analyses. Molecular phylogenetics and Evolution. 101: 56-74.

Chase MW, Douglas ES, Olmstead R \& Albert VA. (1993). Phylogenetics of seed plants - an analysis of nucleotide sequences from the plastid gene rbcL. Ann. Miss. Bot. Gard. 80: $528-580$

Cheek MR (2007). Bombacaceae, Brownlowiaceae, Byttneriaceae, Durionaceae, Helicteraceae, Malvaceae, Pentapetaceae, Sparrmanniaceae, Sterculiaceae, Tiliaceae. In : Heywood, V.H. et. al. (eds.), Flowering plant families of the world. Royal Botanic Gardens, Kew.

Christenhusz MJM and Byng JW (2016). "The number of known plants species in the world and its annual increase". Phytotaxa. 261 (3): 201-217.

Cronquist A (1981). An integrated system of classification of flowering plants. Columbia University Press, New York, NY.

Cronquist A (1988). The evolution and classification of flowering plants, $2^{\text {nd. }}$ ed. New York Botanical Garden, Bronx, NY.

Edlin HL (1935a). A critical revision of certain taxonomic groups of the Malvales. New Phytol. 34(1): 1-20.

Edlin HL (1935b). A critical revision of certain taxonomic groups of the Malvales. New Phytol. 34(2): 122-143.

El Hadidi MN \& Boulos L (1988). The Street trees of Egypt. $2^{\text {nd }}$ ed. America University in Cairo Press, Egypt. 


\section{Eman M. Shamso and Adel A. Khattab}

El Hadidi MN, Hosni HA, El Hadidy A \& Araffa $S$ (1999). Malvaceae in the flora of Egypt, 1- Systematic revision of the indigenous taxa. Taeckholmia 19(2): 127146.

El-Husseini N (2006). Pollen morphology of Tiliaceae Juss. and Sterculiaceae Vent. and their relations to Malvaceae Juss. in Egypt. Int. J. Agri. Bio., 8(6): 844-847.

El Naggar $S$ (2004). Pollen morphology of Egyptian Malvaceae: An Assessment of Taxonomic Value. Turk. J. Bot. 28:227-240.

Erdtman G (1952). "Pollen Morphology and Plant Taxonomy Angiosperm". Almqvist and Wiksell, Stockholm.

Dehay C (1941). L'appareil Libero-Ligneux foliaire des Sterculiaceae. Ann. Sci. Nat. Bot., ser. 2, 45: 127-128.

Doweld A (2001). Prosyllabus Tracheophytorum, Tentamen Systematis Plantarum Vascularium (Tracheophyta). Moscow: GEOS.

Fay MF, Bayer C, Alverson WS, de Bruijn AY \& Chase MW (1998). Plastid rbcL sequence data indicate a close affinity between Diegodendron and Bixa. Taxon 47: 43-50.

Hamdy R \& Shamso E (2010). Pollen Morphology of Sterculiaceae (s. str.) in Egypt and its Taxonomic Significance. Egypt. J. Bot. 50 : 103-117.

Hosni HA \& Araffa S (1999). Malvaceae in the flora of Egypt, 2- Pollen morphology and its taxonomic significance. Taeckholmia 19(2): 127-146.

Hutchinson J (1959). The families of flowering plants, arranged according to a new system based on their probable phylogeny. Dicotyledonae. vol. II. ( $2^{\text {nd }}$ ed.). Macmillan

Hutchinson J (1967). The Genera of Flowering Plants (Angiospermae), vol. II. Clarendon Press, Oxford.

Huxley A, Griffiths M \& Levy M (1992). "The New Royal Horticultural Society Dictionary of Gardening". Vol. 1-4. Marton ward Processing ltd. Scarborough, Yorkshire, UK.

Judd WS \& Manchester SR (1997). Circumscription of Malvaceae (Malvales) as determined by a preliminary cladistic analysis of morphological, anatomical, palynological, and chemical characters. Brittonia 49: 384-405.

Kubitzki K \& Bayer C (2003). Malvales In: Kubitzki (ed.) The Families and Genera of Vascular Plants, Malvales, Capparales and Non - Betalain Caryophyllales vol.5, 225-311. Springer, Berlin, Heidelberg, New

York.

Lakshmi GK (2003). Palynological studies on Certain Malvales, Ph. D. Thesis, Mahatma Gandhi University (On line Thesis).

Linnaeus C (1753). Species Plantarum. Holmiae.

McCune, B. (1997). PC-ord version 5, for Windows. Specifications. [http://home. centurytel. net/ mjm/winspecs.htm].

Nyffeler R, Bayer C, Alverson SA, Yen A, Whitlock BA, Chase MW and Baum DA (2005) Phylogenetic analysis of the Malvadendrina clade (Malvaceae s.1.) based on plastid DNA sequences. Organisms, Diversity \& Evolution 5: 109-123

Péchon Le T \& Gigord LD (2014). On the relevance of molecular tools for taxonomic revision in Malvales, Malvaceae s.l., and Dombeyoideae in P Besse (ed.) Molecular Plant Taxonomy, Methods and Protocols. Chapter 117: 337-363. Springer Science.

Perveen A \& Qaiser M (2007). Pollen Flora of Pakistan-Malvaceae-GrewioideaeLII. Pak. J. Bot. 39(1): 1-7.

Perveen A, Grafström E \& El-Ghazaly G (2004). World Pollen and Spore Flora 23. Malvaceae Adams. P.p. subfamilies: Grewioideae, Tilioideae, Brownloioideae. Grana 43: 129-155.

Reveal JL (2012). An outline of a classification scheme for extant flowering plants. Phytoneuron 37: 1-221.

Schultze-Motel W (1964) in H Melchior (ed.). A. Engler's "Syllabus der Pflanzenfamilian". $12^{\text {th }}$ ed, Gebrüder Borntraeger Verlag, Berlin

Schumann KM (1890). Sterculiaceae. In A Engler \& K Prantl (eds.), Die Natürlichen Pflanzenfamilien 3(6) Wilhelm Engelmann, Leipzig, Germany

Schumann KM (1895). Malvaceae. In A Engler \& K Prantl (eds.), Die Natürlichen Pflanzenfamilien,30-53.Wilhelm Engelmann, Leipzig, Leipzig, Germany. 


\section{Phenetic relationship between Malvaceae s.s.}

Schumann KM (1895). Bombacaceae in A Engler, K Prantl (eds.), Die Natürlichen Pflanzenfamilie,:53-68, Wilhelm Engelmann, Leipzig, Germany

Schumann KM (1897). Tiliaceae. In: A Engler \& K Prantl (eds.) Die Natürlichen Pflanzenfamilien,PP: 232-234. Wilhelm Engelmann, Leipzig, Germany

Shamso E \& Hamdy R (2010). Melhania steudneri (Sterculiaceae) new record for Egypt, and a synopsis of the Sterculiaceae in Egypt. Nordic J. Bot. 28:174-181.

Shipunov AB (2016). Systema Angiospermarum. Version 5.19. website http://ashipunov.info/shipunov/ang/current/sy ang.pdf; (June 1, 2016)

Simpson MG (2010). Plant Systematic. $2^{\text {nd }}$ edition. Boston: Elsevier-Academic Press.

Soltis DE, Soltis PS, Nickrent DL, Johnson LA, Hahn WJ, Hoot SB, Sweere JA, Kuzoff RK, Kron KA, Chase MW, Swensen SM, Zimmer EA, Chase SM, Gillespie LJ, Kress WJ \& Sytsma KJ (1997). Angiosperm phylogeny inferred from $18 \mathrm{~S}$ ribosomal DNA sequences. Ann. Miss. Bot. Gard. 84: 1-49

Stevens PF (2001 onwards). Angiosperm Phylogeny Website. Version 13,
Retrieved 15 July 2014. http://www.mobot. org/ MOBOT/research/APweb/Includes

Takhtajan A (1997). Diversity and Classification of Flowering Plants, Columbia University Press, New York.

Takhtajan A (2009). Flowering plants. $2^{\text {nd }}$ ed. Berlin: Springer-Verlag.

Täckholm V (1974). Students' Flora of Egypt. $\mathbf{2}^{\text {nd }}$ ed. Cairo University.

Thorne RF (1992). An updated phylogenetic classification of the flowering plants. Aliso 13: $365-389$.

Thorne RF \& Reveal JL (2007). An update classification of the class Magnoliopsida (Angiospermae). Bot. Rev. 73:67-181.

Whitlock BA, Bayer C \& Baum DA (2001). Phylogenetic relationships and floral evolution of the Byttnerioideae ("Sterculiaceae" or Malvaceae s.l.) based on sequences of the chloroplast gene, ndhF. Syst. Bot. 26:420-437.

Wilkie P, Clark A, Pennington RT, Cheek M, Bayer C \& Wilcock CC (2006). Phylogenetic relationships with the subfamily Sterculioideae (Malvaceae/SterculiaceaeSterculieae) using the chloroplast gene ndhF. Syst. Bot. 31:160-170.

Appendix (1): List of studied taxa with arranged by families and alphabetical within genera according to Reveal's system (2012).

Family: Malvaceae s.s.

Tribe: Hibisceae

1. Hibiscus micranthus L. f. Suppl. Pl.: 308 1781(1782).

Egypt: Baraq El Samrah, 4-5-1972; Kaiser 489(CAIM)- Wadi Mawaw, G. Elba, 28-1-1962;

V.Täckholm et al. s.n.(CAI) - Sudan: Darfour, Zalingi, Jebel sermi, 5-10-2011; Badawi 1212(CAI)- Jebel Dambobei-Kaora, 25-12-1966; Kassas et al. 1033(CAI)- Arabia: S. Mecca, Gibal Noman, 13-1-1945; Khattab 110(CAI).

2. H. sabdariffa L., Sp. Pl. 2:695-695(1753).

Egypt: North garden, El Saff, 27-10-1961; V.Täckholm s.n.(CAI)- Plant Island, Asuan, 2110-1965; El Mahdi s.n.(CAI)- Sudan: Darfour, Wadi Saleh, 11-10-2011; Badawi 1442(CAI).

3. H. trionum L., Sp. Pl. 2:697(1753).

Egypt: El Fayium, Ibshwai, 5-11-1985; Abdel Ghani 4288(CAI) - Kom Ombo, 19-4-1967; Abdel Salam et al. s.n. (CAI) - Sudan: Near Gadarif, 17-12-1967; Kassas et al. E 537(CAI)Halfa el Gedida, 16-12-1967; ; Kassas et al. E 481(CAI)

4. H. vitifolius L., Sp. Pl. 2:696(1753).

Egypt: Wadi Yahameib, 22-1-1962; V.Täckholm s.n.(CAI)- Gebel Elba, 28-2-1938; Shabetai z 5793 (CAIM)- Sudan: Er kuit (Jebel Essit), 8-12-1966; Kassas et al. 310(CAI)Yemen: on the way Taiz-Ibb, 18-5-1972; Brydolf s.n.(CAI).

5. Pavonia kotschyi Hochst ex Webb., Fragm. Fl. Aethiop.-Aegypt. 43(1854). 


\section{Eman M. Shamso and Adel A. Khattab}

Egypt: Wadi Kansisrob, G. Elba, 25-1-1929; Shabetai 2677 (CAIM)-Wadi Udeib, 8-3-1938; Shabetai 5195 (CAIM)-Sudan: Abu Inoum, Kordofan, 1876, Pfund s.n. (CAI).

6. $\quad$ P. triloba Guill. \& Perr., Fl. Seneg. Tent. 1:50 (1831).

Egypt: G. Elba, 13-2-1932; Drar 334 (CAIM)- Karam Elba mountain, 7-2-1962; V.Täckholm et al. s.n.(CAI)- Sudan: Fasher, Qoz, 25-12-1965, Kassas et al. (CAI)- Arabia: Gebel Arafat, Meccha, 14-1-1945; Khattab K. 1408 (CAI).

Tribe: Gossypieae

7. Gossypium arboreum L., Sp. Pl. 2:693(1753).

Egypt: Siwa Oasis, Ain Shohba, 18-4-1986; El Hadidi s.n. (CAI)- Makhlouf spring, Siwa Oasis, 17-4-1986; A.G.Fahmy 153(CAI).

\section{Tribe: Sideae}

8. $\quad$ Abutilon bidentatum Hochst. ex A. Rich., Tent. Fl. Abyss., 1: 68(1847).

Egypt: Suez road, Wadi Angabiya, 15-2-1954; Shabetai 6308(CAIM)- El Kasr, El Dakhla, Ain Fatima, 9-6-1961; V.Täckholm et al. s.n.(CAI) - Arabia: Yanbo-El Nakhl, 6-2-1944; Khattab F.1371(CAI)- Pakistan: Sewat, W. Pakistan, sept. 1968; Ibrahim s.n. (CAI).

9. A. figarianum Webb., Fragm. Fl. Aethiop. Aegypt.: 52(1854).

Egypt: Wadi Ghweibba, Red Sea Coast, 9-6-1960; V.Täckholm et al. s.n.(CAI)- Sudan: El Ghaba, 18-11-1966; Ghabbour s.n. (CAI)- Near Gedarif, 17-12-1967; Kassas et al. E 509(CAI).

10. A. fruticosum Guill. \& Perr. In Guill. et al., Fl. Seneg. Tent. 1: 70-71(1831).

Egypt: Gebel Elba, 7-2-1962; V.Täckholm et al. s.n.(CAI)- Sinai, Wadi Isla, 4-2-1940; Hassib s.n. (CAI)- Sudan: Kassala -Girger, 12-12-1967; Kassas et al. E 352 (CAI)- Arabia: Gibal Arafat, 18-1-1995; Khattab K 1163 (CAI)- Qater: Um Slal-Mohammed, 6-12-1978; Batanouny 101 (CAI).

11. A. pannosum (G. Forst.) Schlecht., Bot. Zeitung. 9:828 (1851).

Egypt: Qena, E Nag El Bayada, 9-1-1931; Basta s.n. (CAIM)- Foot of Gebel Samiuki, Red Sea Coast, 6-2-1961; V. Täckholm et al. s.n.(CAI)- Sudan: Khartoum, Decemb, 1953; Kassas s.n.(CAI)- Wadi Halva, 25-11-1962; Petterson 16694(CAI).

12. A. theophrasti Medik., Malvenfam. 28(1787).

Egypt: Ezbbet El Awam, Damietta, 13-6-1922; Dsiwfswy 1467 (CAIM)- Fayium, Ibshwai, 36-1983; Abdel Ghani 6490 (CAI)- N. America: New Jersey, 30-7-1974; A. Moldenke \& H. Moldenke 28712 (CAI).

13. Sida alba L., Sp. Pl. ed.2:960(1763).

Egypt: Lahoun, El Fayium, 15-9-1991; S. Araffa s.n. (CAI)- DAkhla Oasis, 4-3-1934; Shabetai 4362 (CAIM)- Sudan: Dafour, Zalingi, Gerei, 30-9-2011; Badawi 1021 (CAI).

Tribe: Malveae

14. Malvella sherardiana (L.) Jaub. \& Spach, III. Pl. Orient. 5(45):46, tab.444 (1855).

Egypt: Dakhla Oasis, 6-3-1934; Shabetai Z 4363(CAIM)- Palestine: Beit Hanoun, N. of Ghaza, 12-11-1964; Boulos s.n.(CAI)- Jordan: Midway between Amman \& Madaba, 7-51974; Boulos \& Jallad s.n.(CAI).

15. Malvastrum coromandelianum (L.) Garcke, Bonplandia, 5(18): 295 (1857).

Egypt: Giza, Zoharia garden at El Gezira, 15-5-1927; G. Täckholm s.n.(CAI)- El Saff, 15-51971; Bircher s.n. (CAI)- India: University Campus, Delhi, India, 10-2-1952; G. Samp s.n.(CAI).

16. Malva aegytia L., Sp. Pl. 2:690(1753).

Egypt: Mersa Matrouh, 22-3-1975; V.Täckholm et al. s.n.(CAI)- Suez road, 21-201960; khattab s.n.(CAIM)- Algeria: Houts-Plateaux oranais, Bedeau: Brossailles, 31-5-1919; Faure s.n. (CAI)- Libya: $25 \mathrm{Km}$ W of Syrte, 8-3-1968; Boulos s.n.(CAI).

17. M. neglecta Wallr, Syll. Pl. Nov. 1: 140 (1824).

Egypt: Deir El Arbaeen, Sinai, 7-5-1980; Abbas s.n. (CAI)- Gebel Katherine, S. Sinai, 7-51939; Drar 342 (CAIM)- Europe: Cobenhagen: Kridtt å rnsvej, 24-9-1939; Lindhardt s.n.(CAI).

18. M. nicaeensis All., Fl. Pedem., 2:40(1785). 


\section{Phenetic relationship between Malvaceae s.s.}

Egypt: Burg El Arab, 1-4-1952; Bot. Dept. Excurs. S.n. (CAI)- Burg El Arab, 25-1-1978; Abdel Wahab s.n. (CAI)- Jordan: Deir Alla Chor, 6-2-1973, Boulos \& Al-Eisawi s.n.(CAI).

19. M. parviflora L., Demonstr. Pl., 18 (1753).

Egypt: Saqqara fields, 15-3-1992, S. Araffa s.n. (CAI)- N. Abu Zeneima, 13-4-1962; Abdallah 534(CAIM)- Libya: Near Al Kararim, 8-3-1968, Boulos s.n.(CAI)- Sudan: Khartoum, 1924; Shabetai 27 (CAI).

20. M. sylvestris L., Sp. Pl., 2:689(1753).

Egypt: Sallum, Wadi El Ramlah, 14-4-1934; Shabetai 3071(CAIM)- Cairo-Alexanderia road, S El Amriya, 12-3-1991; S. Araffa s.n.(CAI)- Libya: Near Al Kararim, 8-3-1968; Boulos S.n. (CAI)-

21. Althaea ludwigii L., Mant. 98(1771).

Egypt: Wadi Hereidin, S El Arish, 5-4-1939; Drar s.n.(CAIM)-

Cairo-Suez road, 15-1-1960; V.Täckholm s.n.(CAI)- N Galala, 11-4-1924; Simpson 2743 (CAIM)- Arabia: El Kharg road, Jan.1969; Migahid 52 (CAI)- Jordan: Azzraq Oasis, Vicinity of the hot spring, 14-5-1976; V.Täckholm et al. s.n.(CAI).

22. Alcea striata Alef., Österr. Bot. Z. 12: 252 (1862).

Egypt: Deir El Arbain, Sinai, 12-5-1956; El Hadidi s.n.(CAI)- Garden of Deir El Arbain, Sinai, 24-4-1961; V.Täckholm et al. s.n.(CAI).

23. Lavatera cretica L., Sp. Pl. 2:691(1753).

Egypt: Burg El Arab, 22-3-1956; El Hadidi s.n. (CAI)-Giza, 22-5-1964; Shabetai 2908 (CAIM)- Libya: Ministry of Agriculture, Sidi El Masri, Tripoli, 16-4-1967; Boulos s.n. (CAI).

Family: Dombeyaceae

24. Melhania denhamii R. Br., Narr. Travels Africa 232 (1826).

Egypt: W. Aideib, G. Elba, 5-2-1933; Shabetai 2762(CAIM)- W. Laseitit, G. Elba, 7-2-1962; V.Täckholm et al. s.n.(CAI).

25. M. phillipsiae Baker f., J. Bot. 36: 4 (1895).

Egypt: G. Karam, Elba, 7-2-1962; V.Täckholm et al. s.n.(CAI)- Northwest and west slopes of Gebel Asotriba, 28-1-1962; V.Täckholm et al. s.n.(CAI).

26. M. steudneri Schweinf., Verh. K.K. Zool . - Bot. Ges. Wien 18: $\quad$ 672(1868).

Egypt: W. Yahameib, 26-1-1933; Drar 256a/33(CAIM)- Near Halaieb, W. Ararat, Jan. 1954; Bolland 214(CAIM)- Sudan: Qoz, abu Dellia, 12-9-1954; Kassas 612 (CAI).

27. Dombeya Burgessiae Gerr. ex Harv., Fl. Cap. 2: 590 (1862).

Egypt: Barrage Medicinal garden, Qaliubiya, 8-1-1961; V. Täckholm et al. s.n.(CAI)- Orman garden, Giza, 1-11-2008; R. Hamdy s.n.(CAI).

28. D. tiliacea (Endl.) Planch., Fl. Serres. Jard. Eur. 6: 225(1851).

Egypt: Orman garden, Giza, 29-11-1966; Fawzi \& Magida s.n.(CAIM)- Orman garden, Giza, 1-11-2008; R. Hamdy s.n.(CAI).

29. Pterospermum acerifolium (L.) Willd., Sp. Pl. 3(1): 729(1800).

Egypt: North garden, El Saff, 23-6-1961; V. Täckholm s.n.(CAI)- Botanical Island, Aswan, 15-4-1964; M. El Mahdi s.n.(CAI).

Family: Byttneriaceae

Tribe: Byttnerieae

30. Abroma augusta (L.) L.f., Suppl. Pl. 341(1782).

Egypt: Agricultural Museum gardens, Dokki, 4-7-1956; Mahdy s.n.(CAI).

Tribe: Hermanniaceae

31. Hermannia Cuneifolia Jacq., Pl. Rar. Hort. Schoenbr. 1:66(1797)

Egypt: Agriculture Museum gardens, Dokki, 10-2-1947; Khattab G.1512 (CAIM).

32. H. modesta (Ehrenb.) Mast., Fl. Trop. Afr. 1: 232(1858).

Egypt: Wadi Aideib, Gebel Elba, 20-1-1933; Shabetai F. 1061(CAIM)- Gebel Karam Elba, Gebel Elba, 7-2-1962; V.Täckholm et al. s.n.(CAI)- Sudan: Jebel Gumbereit, 16-1-1956; Kassas s.n.(CAI).

33. Waltheria indica L., Sp. Pl. ed. 1: 673(1753). 


\section{Eman M. Shamso and Adel A. Khattab}

Egypt: W Aideib, Gebel Elba, 13-9-1936; Drar 150/36(CAIM)- Gebel Ekwal, Gebel Elba, 26-1-1933; Shabetai z 2764(CAIM)- Sudan: Jebel Dahand, Red Sea, 11-12-1966, Kassas et. al. s.n.(CAI).

Tribe: Theobromeae

34. Glossostemon bruguieri Desf., Mém. Mus. Hist. Nat. 3: 239(1817)

Egypt: Fac. of Pharmacy, Cairo Univ, 15-10-1963; M. El Mahdi s.n.(CAI)- Agricultural Museum gardens, Dokki, 16-5-1964; Khattab s.n.(CAIM).

35. Guazuma ulmifolia Lam., Encycl. 3: 52(1789).

Egypt: Orman garden, Giza, 27-10-1959; ; V. Täckholm s.n.(CAI)- Botanical Island, Aswan, 9-12-1996; H. Rafaeel 29189(CAIM).

Family: Sterculiaceae s.s.

36. Brachyciton acerifolius (A. Cunn. ex G. Don) Macathur, Cat. Coll. Bois Indig 6: 116(1855). Egypt: Agricultural Museum gardens, Dokki, 7-5-1952; Shabetai \& Abdallah G. 1951(CAIM)- Orman garden, Giza, 26-5-1968; El Mahdi s.n. (CAI).

37. B. australis (Schott \& Endle.) A. Terracc., Boll. Reale Orto Bot. Palermo 1(2): 54, 62(1897). Egypt: Orman garden, Giza, 5-9-1999; Labib s.n. (CAI)- Orman garden, Giza, 111-2008; R. Hamdy s.n.(CAI)

38. B. discolor F. Muell., Fragm. 1: 1(1858).

Egypt: Ezbekieh garden, Cairo, 20-5-1933; Shabetai G.1593 (CAIM)- Alfred bircher's Northeastern garden, El saff, 23,6,1961; V.Täckholm et al. s.n.(CAI).

39. B. populneus (Schott \& Endl.) R. Br., Pterocymbium 234(1844).

Egypt: Orman gardrn, Giza, 12-4-1928; Hassib s.n.(CAI)- Botanical Island, Aswan, 16-42007; H. Rafaeel 29353(CAIM).

40. B. rupestris (T. Mitch. ex Lindl.) K. Schum., Nat. Pflanzenfam. 3(6): 96(1893).

Egypt: Orman garden, Giza, 20-4-2009; R. Hamdy s.n.(CAI)- Aswan, Botanical Island, 2110-1965; M. El Mahdi s.n.(CAI).

41. Firmiana simplex (L.) W. Wight, Bull. Bur. Pl. Industr. U.S.D.A. 142: 67(1909).

Egypt: Zoological garden, Giza, 31-5-1969; M. EL Mahdi s.n. (CAI)- Botanical Island, Aswan, 5-5-2007; H. Rafaeel 19365(CAIM).

42. Pterygota alata (Roxb.) R. Br., Pterocymbium 234(1844).

Egypt: Giza. Zoological Garden, 9-10-1966; K. Fawzi s.n. (CAI)- El saff garden, 23-6-1961; V. Täckholm \& El Sayed. s.n.(CAI).

43. Sterculia africana (Lour.) Fiori, Agric. Colon. 5(suppl.) 37(1912).

Egypt: Gebel Akaw, 8-3-1938; Shabetai 5530 (CAIM)- Sudan: Red Sea, G. Dahand, 6-21961, V.Täckholm et al. s.n.(CAI)- Jebel Dahand, Red sea, 11-12-1966, Kassas et al. 559(CAI).

44. S. foetida L., Sp. Pl. ed. 1:1008 (1753).

Egypt: Zoological garden, Giza, 9-10-1966; Fawzi \& Khattab s.n.(CAIM)- Aswan, Botanical Island, 9-12-1996; H. Rafaeel s.n.(CAI).

\section{Family: Sparrmanniaceae}

Tribe: Grewieae

45. Corchorus depressus (L.) Stocks, Proc. Linn. Soc. London 1:367(1848).

Egypt: Mersa Halaib, at the shore of the Red Sea, 20-1-1-1929; G. Täckholm s.n.(CAI)Gebel El Faraied, Red Sea, near the well, 12-2-1961; V.Täckholm et al. s.n.(CAI)- Arabia: Abu Shoaib, Wadi Fatma; 9-1-1945; Khattab k. 1083(CAI)- El Kharag road, 26-1-1969; Migahid s.n.(CAI).

46. C. olitorius L., Sp.Pl. 1: 529(1753).

Egypt: Ali Bey SW of Madinet El Faiyum, 21-11-1926; G. Täckholm s.n.(CAI)- Aswan, in the field at the new station, 18-1-1927; G. Täckholm s.n.(CAI)- Arabia: El Gomam, Wadi Fatma, 8-1-1945; Khattab k. 1057(CAI)- Kuwait: University Campus at Khaldiya, 8-101986; Boulos \& Al Hasan s.n.(CAI).

47. C. tridens L. Mant. P1. 2: 566(1771). 


\section{Phenetic relationship between Malvaceae s.s.}

Egypt: Expedition to Gebel Elba, January 1962; V.Täckholm et al. s.n.(CAI)- Nag El Ismailia, Ballana, 22-12-1963; Boulos s.n.(CAI)- Sudan: Near Om Durman, 14-9-1953; Kassas 66(CAI).

48. C. trilocularis L. Mant. Pl. 1:77(1767).

Egypt: Beheira province, Rosetta, 18-8-1987; A. Amer 12691(CAI)- El Heiz, Ain El-Ezza, Bahariya Oasis, 5-10-1978; El Ghani 2760 (CAI)- Sudan: Khor Arabaat, Port Sudan; 16-121966, Kassas et al. 770 (CAI)- Jordan: Deir Alla, Northern Ghor, 15-11-1973; Boulos \& AlEisawi s.n.(CAI)- Yeman: Between Ibs \& El Zohra, 28-3-1944; Khattab f. 5621(CAI).

49. Grewia tembensis Fresen., Mus. Senckenberg. 2:158(1837).

Egypt: W. Haikwal, G. Elba, 27-1-1933; Hassib s.n.(CAI)- W. Yehmit, G. Elbas, Jan. 1933; Hassib s.n.(CAI)- Arabia: Gebel Radwa, Yanboa, 27-2-1945; Khattab k. 1444 (CAI).

50. G. tenax (Forssk.) Fiori,, Agric. Colon. 5(Suppl.):23 (1912).

Egypt: Khor across the north-eastern slops of Gebel elba, 21-1-1962; V.Täckholm et al. s.n. (CAI)- Gebel Karam, Elba, 7-2-1962, V.Täckholm et al. s.n. (CAI)- Sudan: way to El Obaied, Kordafan, 1-5-1938; Drar s.n.(CAI).

51. G. villosa Willd., Neue Schriften Ges. Naturf. Freunde Berlin 4:205(1803).

Egypt: Gebel Elba, April 1932; Drar s.n.(CAI)- W. Akaw, G. Elba, 2-2-1933; Hassib s.n. (CAI)- Sudan: Gebel Marra, 21-12-1965; Kassas et al. 732(CAI).

52. Triumfetta flavescens Hochst. Ex A. Rich., Tent. Fl. Abyss. 1:82(1847).

Egypt: Wadi at the foot of Gebel Elba, 20-1-1962; V.Täckholm et al. s.n. (CAI)- Gebel Elba, April 1932; Drar s.n.(CAI)- Sudan: Jebel wadi Nobao, Red Sea, 23-12-1966; Kassas et al. 975 (CAI)- Arabia: Arafat, Gebal Chaddad, 27-1-1945; Khattab k. 1177(CAI).

53. T. rhomboidea Jacq., Enum. Syst. Pl. 22(1760).

Sudan: Darfour, Zalingi, Ban Jadeed, Ghor Abundoboba, 8-10-2011; Badawi 1360 (CAI)Sunni, G. Marra, 23-12-1965; Kassas et al. 853 (CAI).

Family: Tiliaceae $s . s$.

54. Tilia americana L., Sp. Pl. 1:514(1753).

Europe: Becch-maple forest in Burt lake region, Michigan, Aug. 1921; Frank s.n. (CAI)Breslan, Städtischer Botanischer Garten, 11-8-1911; C. Baenitz s.n. (CAI).

55. T. cordata Mill., Gard. Dict. ed. 8, no. 1(1768).

Europe: Zealand, Jonstrup Vang (Denmark), 8-8-1890; Mortensen s.n.(CAI)- Collected around the alpine station, " La Linnaea" Burg St. Pierre, Switzerland, June-August 1936; Migahid \& Montasir s.n.(CAI).

56. T. platyphyllos Scop., Fl. Carniol. ed. 2, 1: 373(1771).

Europe: Collected around the alpine station, " La Linnaea" Burg St. Pierre, Switzerland, June-August 1936; Migahid \& Montasir s.n.(CAI)- Peninsula Mals, Krakaer, Denmark, 167-1969; Holm-Nielson \& Jeppesen s.n.(CAI).

57. T. tomentosa Moench, Verz. Ausländ. Bäume 136(1785).

Europe: Sweden: Lund, 8-8-1976; El Gazzar s.n.(CAI)- Breslau, Göpperthain, 10-9-1911; Baenitz s.n.(CAI).

Family: Bombacaceae

Tribe: Adansonieae (sensu Carvalho-Sobrinho 2016)

58. Adansonia digitata L., Syst. Nat. ed. 10, 2:1144(1759).

Egypt: Plant island, Assuan, 21-10-1965; El Mahdi s.n.(CAI)- Mounira Hospital garden, Cairo, 2-11-1959; I. El Sayed s.n.(CAI)- Sudan: El Obeiyad, Kordofan, 1924; Shabetai s.n.(CAI)- Nyala, 27-12-1965; Kassas et al. 1012 (CAI).

Tribe: Bombaceae (sensu Carvalho-Sobrinho 2016)

59. Ceiba pentandra (L.) Gaertn., Fruct. Sem. Pl. 2:244(1791).

Egypt: Plant Island, Assuan, 14-4-1964; El Mahdi s.n. (CAI)- $\underline{\text { Sudan: }}$ Kurmek, 28-12-1967; E. 983 Kassas et al. (CAI).

60. Bombax malabaricum DC., Prodr. 1:479(1824).

Egypt: Zoological garden, Giza, 25-3-1964; El Mahdi s.n.(CAI)- Faculty of Agriculture, Giza, Spring 1963; Sisi s.n.(CAI)- Plant Island, Assuan, Febr. 1966; L. Croneborg s.n. (CAI). 


\section{Eman M. Shamso and Adel A. Khattab}

61. Chorisia crispiflora Kunth, Nov. Gen. Sp. 5: 295(1822).

= Ceiba crispiflora (Kunth) Ravenna, Onira 3(15):47(1988).

Egypt: Plant Island, Assuan, 24-10-1965, El Mahdi s.n.(CAI)- Kafr Shoukkr, in the garden of Prof. Efflatoun, 1-11-1953; V.Täckholm s.n. (CAI)- El Shams club gardens, Cairo, 3-111973; A. Gazzar s.n.(CAI).

62. Ch. insignis Kunth, Nov. Gen. Sp. 5: 295(1822).

= Ceiba insignis (Kunth) P.E. Gibbs \& Semir, Notes Roy. Bot. Gard. Edinburgh 45: 134(1988).

Egypt: Plant Island, Assuan, 24-10-1965; El Mahdi s.n.(CAI)-

Northeastern garden, Alfred Bircher' garden, El Saff, 22-11-1961; V.Täckholm \& I. El Sayed s.n. (CAI).

63. Ch. speciosa A.St.-Hil., Pl. Usuel. Bras. t. 63 (1828).

= Ceiba speciosa (A.St.-Hil.) Ravenna, Onira 3(15):46(1998).

Egypt: Zoological garden, Giza, 3-11-1963; El Mahdi s.n. (CAI)- Orman garden, Giza, 1010-1961; Drar s.n. (CAI).

64. Pachira macrocarpa (Schltdl. \& Cham.) Walp., Repert. Bot. Syst. 1:329(1842).

Egypt: Zoological garden, Giza, 9-8-1972; El Mahdi s.n.(CAI)- Cultivated in Alfred Bircher's garden, El Saff, 10-6-1960; V.Täckholm s.n. (CAI).

\section{Appendix (2): A list of characters and characters states used in morphometric analysis of the} studied taxa of Malvaceae and allied families:

1. Habit: herb (1), Low shrub to shrub (2), Tree (3).

2. Duration: annual (1), Perennial (2), Annual or Perennial (3).

3. Stem branching: Erect (1), Erect to ascending (2), procumbent (3).

4. Stem length: up to $50 \mathrm{~cm}(1), 50-100 \mathrm{~cm} \mathrm{(2),} \mathrm{more} \mathrm{than} 100 \mathrm{~cm}(3)$.

5. Stem texture: glabrous to subglabrous (1), sparcely to densely hairy (2), Prickly (3).

6. Leaf duration: evergreen (1), deciduous (2)

7. Leaf venation: pinnately nerved (1), Palmately nerved (2)

8. Leaf composition: simple (1), lobed (2), simple \& lobed (3), almately compound (4).

9. Shape of simple leaves or leaflets: ovate to cordate (1), reniform-orbicular (2), lanceolate to elliptic (3), rhomobid-ovate or ob-triangular (4).

10. Length of leaf blade: up to $10 \mathrm{~cm}$ long (1), more than $10 \mathrm{~cm}$ long (2).

11. Width of leaf blade: up to $4 \mathrm{~cm}$ wide (1), more than $4 \mathrm{~cm}$ wide (2).

12. Surface of leaf: glabrous (1), hairy (2).

13. Leaf margin: entire (1), dentate to crenate (2).

14. Leaf petiole: petiolate (1), sessile (2).

15. Petiole length: up to $5 \mathrm{~cm}$ long (1), more than $5 \mathrm{~cm}$ long (2).

16. Stipules duration: Persistent (1), deciduous (2).

17. Stipules shape: linear- lanceolate (1), ovate (2), subulate (3), leafy (4).

18. Stipules length: less than $5 \mathrm{~mm}(1)$, more than $5 \mathrm{~mm} \mathrm{(2).}$

19. Flowers sexuality: unisexual or polygamous (1), bisexual (2).

20. Flower diameter: up to $10 \mathrm{~mm} \operatorname{dim}$. (1), 10-20 mm dim. (2) more than $20 \mathrm{~mm} \mathrm{dim}$. (3).

21. Flower arrangement: solitary (1), arrangred in inflorescence (2)

22. Types of inflorescence: terminal or axillary racemes (1), axillary cymes (spreading to compact) (2), fascicles (3).

23. Bracts: similar to the folliage leaves (1), different from the foliage leaves (2)

24. Base of bracts: adnate to the peduncle (1), not adnate to the peduncle (2).

25. Pedicel length: up to $10 \mathrm{~mm}(1)$, more than $10 \mathrm{~mm}(2)$.

26. Presence of epicalyx (bracteoles): present (1), absent (2).

27. Number of epicalyx segments (bracteoles): 1 - 3 (1), 6-12 (2).

28. Union of epicalyx segments (bracteoles): free (1), connate at base (2).

29. Duration of epicalyx (bracteoles): persistent (1), deciduous (2).

30. Shape of epicalyx segments (bracteoles): ovate to broadly cordate (1), linear to lanceolate (2), reniform (3).

31. Length of epicalyx segments (bracteoles): up to10 $\mathrm{mm}$ long (1), more than $10 \mathrm{~mm}$ long (2).

32. Calyx color: green (1), reddish (2), yellow to brownish (3), white (4)

33. Calyx length: up to $10 \mathrm{~mm}$ long (1), more than $10 \mathrm{~mm}$ long (2).

34. Number of sepals: (3-) 4- sepals (1), 5-(6-) sepals (2).

35. Size of calyx lobes: equal lobes (1), unequal lobes (2).

36. Calyx lobes: connate up to the middle (1), completely connate (2), free (3).

37. Shape of lobes: lanceolate to elliptic (1), ovate to broadly ovate (2). 


\section{Phenetic relationship between Malvaceae s.s.}

38. Apex of lobes: acute (1), acuminate or awned (2).

39. Presence of corolla: present (1), absent (2)

40. Color of corolla: pink to mauve (1), yellow to orange (2), white (3), reddish (4).

41. Number of petals: 4 - petals (1), 5- petals (2).

42. Union of petals: free (1), connate from base (2).

43. Petals differentiation: differentiated into claw and limb (1), undifferentiated (2).

44. Length of corolla: up to $15 \mathrm{~mm}$ long (1), 15-50mm long (2), more than $50 \mathrm{~mm}$ long (3).

45. Length of Corolla/Calyx: as long as calyx (1), longer than calyx (2), shorter than calyx (3).

46. Apex of petals: acute or round (1), emarginate or partite (2).

47. Base of petals: with bearded base (1), without bearded base (2), hooded-concave base (3).

48. Androecium: 5 stamens (1), (8-)10 stamens (2), more than 10 stamens (3).

49. Connation of stamens: free (1), fascicles (2), half or completely united (monodelphous) (3), fascicles and monodelphous (4).

50. Surface of staminal tube or stamens: glabrous (1), hairy (2)

51. Length of staminal tube or stamens: up to $10 \mathrm{~mm}$ long (1), more than $10 \mathrm{~mm}$ long (2).

52. Length of staminal tube or stamens/petals: as long as (1), shorter than petals (2).

53. Number of Anther's cell: Unicelled (1), bicelled (2).

54. Distribution of anthers: restricted to the upper part of the staminal tube or as collar (1), spreading along the surface of the staminal tube (2).

55. Presence of staminodial appendages: absent (1), present (2).

56. Shape and position of staminodial appendages: Spathulate or triangular and alternate with stamens (1), Coronalike and whorled at the lower part of the staminal tube (2).

57. Style position: concentric (1), excentric (2).

58. Style connation: free (1), connate below to completely united (2).

59. Number of styles: 1 (1), 3-5 (2), more than 5 (3).

60. Style branches: erect (1), curved (2).

61. Surface of styles: glabrous (1), papillose (2).

62. Number of styles or stigmas/carpels: as many as carpels (1), twice as many as carpels (2).

63. Shape of stigma: capitate to clavate (1), filiform-decurrent (2), linear to lobed (3).

64. Number of carpels: 1-2 (1), 3-5 (2), more than 5 (3).

65. Number of locules for each ovary: uni- biloculed (1), 3-5 loculed (2), more than 5 loculed (3).

66. Number of ovules per locule: 1 (1), 2-3(-4) (2) more than 4 (3).

67. Presence of carpophore: present (1), absent (2).

68. Types of fruits: capsule (1), schizocarp (2), follicle (3), drupe (4), nutlet (5).

69. Color of fruits: yellowish-brown to dark brown (1), green to greenish black (2), orange to red (3).

70. Shape of fruits: ovoid to obovid (1), globose to subglobose (2), cylindrical to elliptic (3), discoid or depresses globoid (4), turbinate (5).

71. Nature of fruit: woody (1), non woody (2).

72. Length of fruits: less than $2 \mathrm{~cm}(1), 2-10 \mathrm{~cm}(2)$, more than $10 \mathrm{~cm}(3)$.

73. Width of fruits: less than $15 \mathrm{~mm}(1)$, more than $15 \mathrm{~mm}(2)$.

74. Outer surface of fruits: glabrous (1), hairy (2), strongly echinate processes (3), tuberculate processes (4).

75. Inner surface of fruits: glabrous (1), hairy (2).

76. Apex of fruits: obtuse (1), acute to beaked (2), notched (3), depressed (4).

77. Fruit outline: terete (1), angled (2), lobed (3), flattened (4).

78. Dehiscence of fruits: dehiscent (1), indehiscent (2).

79. Number of mericarps: 5 (1), 7-10 (2), more than 10 (3).

80. Dehiscence of mericarps: dehiscent (1), indehiscent (2).

81. Shape of mericarps: reniform (1), trigonous (2), inflated (3).

82. Apex of Mericarps: rounded (1), acute to acuminate (2), bi-dentate or awned (3).

83. Dorsal margin of mericarp: winged (1), ridged (2), not winged or ridged (3).

84. Lateral faces of mericarp: smooth (1), ribbed (2).

85. Enclosing of the seeds: enclosed by hony comb-like exotestas (1), without exotestas (2).

86. Number of seeds per mericarp, locule of capsule, follicle or drup: 1(2-) seeded (1), 2-4 seeded (2), more than 4 (3).

87. Shape of seeds: reniform (1), subspheroidal-spheroidal (2), ellipsoid to pyriform (3), ovoid (4), smara-like (5).

88. Dimension of seeds: less than $3 \mathrm{~mm}$ diam. (1), more than $3 \mathrm{~mm}$ diam. (2).

89. Hilum; distinct (1), indistinct (2).

90. Position of hilum: terminal to subterminal (1), ventral (2).

91. Seed hairiness: glabrous (1), slightly hairy (2), densely wooly hairs (3).

92. Seed color: pale brown to dark brown (1), blackish (2), greyish mottled with brown (3).

93. Seed outline: teret (1), 3-4 angles (2), 2- lateral ridges (3), with membranous margin (4).

94. Seed coat surface: obscure to smooth (1), alveolate to reticulate (2), papillate to tuberculate (3), ruminate to rugose (4), striate (5).

95. Dimension of pollen grains: less than $50 \mu \mathrm{m}(1)$, more than $100 \mu \mathrm{m}(2)$

96. Aperture type: porate (1), colporate (2), brevicolpate (3).

97. Number of apertures: 3 pores (1), $4-5$ pores (2), numerous pores (3). 


\section{Eman M. Shamso and Adel A. Khattab}

98. Length of colpus: less than $10 \mu \mathrm{m}(1), 10-20 \mu \mathrm{m}(2), 20-35 \mu \mathrm{m}(3)$.

99. Diameter of pores: less than $5 \mu \mathrm{m}$ (1), more than $5 \mu \mathrm{m}$ (2).

100. Exine sculpture: echinate-foveolate (1), echinate-granulate (2) reticulate-perforate (3), reticulate (4) .

101. Length of spines: $0.5-10 \mu \mathrm{m}$ long (1), 10-25 (-37) $\mu \mathrm{m}$ long (2).

102. Spines apex: acute apex (1), blunt apex (2).

103. Spines base: pulvinous base (1), cushions base (2).

\section{Appendix (3) Abbreviation of taxa name}

\begin{tabular}{|c|c|}
\hline 1. Hibiscus trionum & Hib 1 \\
\hline 2. H. micranthus & Hib 2 \\
\hline 3. H. vitifolius & Hib 3 \\
\hline 4. H. sabdariffa & Hib 4 \\
\hline 5. Gossypium arboreum & Goss \\
\hline 6. Abutilon theophrasti & Abu 1 \\
\hline 7. A. bidentatum & $A b u 2$ \\
\hline 8. A. fruticosum & $A b u 3$ \\
\hline 9. A. pannosum & $A b u 4$ \\
\hline 10. A. figarianum & $A b u 5$ \\
\hline 11. Sida alba & Sida \\
\hline 12. Malvella sherardiana & Mlvla \\
\hline 13. Malvastrum coromandeliana & Mlvst \\
\hline 14. Malva aegytia & Mlv 1 \\
\hline 15. M. parviflora & Mlv2 \\
\hline 16. M. nicaeensis & Mlv3 \\
\hline 17. M. neglecta & Mlv4 \\
\hline 18. M. sylvestris & Mlv5 \\
\hline 19. Althaeae ludwigii & Altha \\
\hline 20. Alcea striata & Alce \\
\hline 21. Lavatera cretica & Lvtr \\
\hline 22. Pavonia kotschy & Pvon 1 \\
\hline 23. P. triloba & Pvon 2 \\
\hline 24. Melhania steudneria & Mlhn 1 \\
\hline 25. M. denhamii & Mlhn 2 \\
\hline 26. M. phillipsiae & Mlhn 3 \\
\hline 27. Hermania modesta & Hrmn 1 \\
\hline 28. H. Cunifolia & Hrmn 2 \\
\hline 29. Waltheria indica & Wlth \\
\hline 30. Sterculia africana & Strc 1 \\
\hline 31. $\quad$ S. foetida & Strc 2 \\
\hline 32. Brachyciton acerifolius & Brch 1 \\
\hline 33. B. australis & Brch 2 \\
\hline 34. B. discolor & Brch 3 \\
\hline 35. B. populneus & Brch 4 \\
\hline 36. B. rupestris & Brch 5 \\
\hline 37. Dombya tiliaceae & Domb 1 \\
\hline 38. D. Burgassiae & Domb 2 \\
\hline 39. Firmiana simplex & Firm \\
\hline 40. Pterygota alata & Ptrg \\
\hline 41. Glossostemon bruguieri & Glst \\
\hline 42. Guazuma ulmifolia & $G u z$ \\
\hline 43. Abroma augustem & Abrm \\
\hline 44. Pterospermum acerifolium & Ptrsp \\
\hline 45. Corchorus depressus & Corc 1 \\
\hline 46. C. olitorius & Corc 2 \\
\hline 47. C. tridens & Corc 3 \\
\hline 48. C. trilocularis & Corc 4 \\
\hline 49. Triumfetta rhomboidea & Trmf 1 \\
\hline 50. T. flavescens & Trmf 2 \\
\hline 51. Grewia tenax & Grw 1 \\
\hline 52. G. villosa & Grw 2 \\
\hline
\end{tabular}


Phenetic relationship between Malvaceae s.s.

\begin{tabular}{|c|c|}
\hline 53. G. tembensis & Grw3 \\
\hline 54. Tilia americana & Til 1 \\
\hline 55. T. Platyphyllos & Til 2 \\
\hline 56. T. cordata & Til 3 \\
\hline 57. T. Tomentosa & Til 4 \\
\hline 58. Adansonia digitata & Adns \\
\hline 59. Pachira macrocarpa & Pach \\
\hline 60. Bombax malabaricum & Bomb \\
\hline 61. Ceiba pentandra & Ceib \\
\hline 62. Chorisia insignis & Chor 1 \\
\hline 63. Chorisia speciosa & Chor 2 \\
\hline 64. Chorisia crispiflora & Chor 3 \\
\hline
\end{tabular}

